\title{
УДК 091"18":027.54(477-25)НБУВ
}

\section{Цитування:}

Підгорбунський М. А. Тлумачення невменних знаків із рукописної «Азбуки співочої». Вісник Національної академії керівних кадрів культури $i$ мистеитв : наук. журнал. № 2. Київ : ІДЕЯ ПРИНТ, 2020. С. 214-221.

Pidhorbunskyi M. (2020). Interpretation of neume signs from the handwritten "Alphabet of the Singing». National Academy of Culture and Arts Management Herald: Science journal, 2, 214-221 [in Ukrainian].

\author{
Підгорбунський Микола Анатолійович, \\ кандидат історичних наук, доиент, \\ доиент Київського національного університету \\ культури і мистецтв \\ ORCID: https://orcid.org/0000-0002-2678-5147 \\ nikolauspidg@gmail.com
}

\section{ТЛУМАЧЕННЯ НЕВМЕННИХ ЗНАКІВ ІЗ РУКОПИСНОЇ «АЗБУКИ СПІВОЧОЇ»}

Метою статті $є$ проведення палеографічного опису та виявлення характерних особливостей у формуванні азбуктлумачень в XVIII - XIX ст. Методологія дослідження включає системний аналіз, що сприяв осмисленню рукописних півчих азбук-тлумачень. Для окреслення часових і кількісних характеристик досліджуваного матеріалу використано статистичний та хронологічний методи. Наукова новизна - полягає у тлумаченні простих, складених невменних знаків, сформованих в групи за напрямком руху мелодії та ритмікою. Висновки. Палеографічний аналіз Азбуки співочої ф. 301, № 638 п, дав можливість виявити певні закономірності, знайти спільні риси та відмінності 3 іншими рукописними азбуками. Визначено, що з XVIII і до початку XIX ст. півчі азбуки мають не тільки перелік невм, а й їхнє тлумачення та розділення невменних знаків на групи за напрямком руху мелодії та ритмікою. В результаті аналізу рукописних збірок встановлено, що наповнення невменними знаками азбук, як і в XVI ст., так і в наступних століттях, відбувалося відповідно до їхнього використання під час співочої практики. Як правило, в азбуку вносилися ті знаки, які вважалися найбільш важливими у виконанні церковних піснеспівів. Під час проведення дослідження проаналізовано п’ять груп невматичних знаків, які розташовані наприкінці півчої азбуки. Визначено їхні характерні особливості: встановлено звуковисотність, кількість звуків та мелодичну направленність невменних знаків.

Ключові слова: співоча азбука, рукописний збірник, азбука-тлумачення, невменні знаки.

Подгорбунский Николай Анатольевич, кандидат исторических наук, дочеет, доцент Киевского национального университета культуры и искусств

Толкование невменных знаков с рукописной «Азбуки певчей»

Целью статьи является проведение палеографического описания и выявления характерных особенностей в формировании азбук-толкований в XVIII - XIX в. Методология исследования включает системный анализ, который способствовал осмыслению рукописных певчих азбук-толкований. Для определения временных и количественных характеристик исследуемого материала использованы статистический и хронологический методы. Научная новизна - заключается в толковании простых, составных невменных знаков, сформированных в группы по направлению движения мелодии и ритмикой. Выводы. Палеографический анализ Азбуки певческой ф. 301, № 638 п, позволил выявить определенные закономерности, найти общие черты и различия с другими рукописными азбуками. Определено, что с XVIII и до начала XIX в. певчие азбуки имеют не только перечень невм, но и их толкование и разделение невменных знаков на группы по направлению движения мелодии и ритмикой. В результате анализа рукописных сборников установлено, что наполнение невменными знаками азбук, как и в XVI в., так и в последующих веках, происходило в соответствии с их использования во время певческой практики. Как правило, в азбуку вносились те знаки, которые считались наиболее важными в исполнении церковных песнопений. Во время проведения исследования проанализированы пять групп невменных знаков, расположенных в конце певческой азбуки. Определены их характерные особенности: установлена звуковисотнисть, количество звуков и мелодичную направленность невменных знаков.

Ключевые слова: певческая азбука, рукописный сборник, азбука-толкование, невменные знаки.

Pidhorbunskyi Mykola, Candidate of Historical Sciences, Associate Professor, Associate Professor of Kyiv National University of Culture and Arts

Interpretation of neume signs from the handwritten «Alphabet of the Singing»

The purpose of the article is to carrying out a paleographic description and identifying characteristic features in the formation of ABC interpretations in the XVIII-XIX centuries. The methodology includes system analysis, which contributed to the comprehension of handwritten singing alphabet interpretations. To determine the temporal and quantitative characteristics of the studied material, statistical, and chronological methods are used. The scientific novelty lies in the interpretation of simple, 


\section{Вісник Національної академії керівних кадрів культури і мистецтв № 2'2о20}

composed neume signs formed in groups in the direction of movement of the melody and rhythm. Conclusions. Paleographic analysis of the $\mathrm{ABC}$ of singing f. 301, No. 638 p, allowed to identify certain patterns, to find common features and differences with other handwritten ABCs. It is determined from the XVIII to the beginning of the XIX century. song alphabets have not only a list of neume but also their interpretation and division of neume signs into groups in the direction of movement of the melody and rhythm. As a result of the analysis of manuscript collections, it was established that the filling with alphabet of insignificant characters, both in the 16th century and in subsequent centuries, occurred in accordance with their use during singing practice. As a rule, those signs that were considered the most important in the performance of church hymns were introduced into the alphabet. During the study, five groups of neume signs located at the end of the song alphabet were analyzed. Their characteristic features are determined: sound hundreds are established, the number of sounds, and the melodic orientation of neume signs.

Key words: singing alphabet, handwritten collection, interpretation alphabet, neume signs.

Актуальність цієї публікації пов’язана зі зростаючою увагою до історичного минулого Української Православної Церкви. Рукописні півчі збірники Православної церкви мають величезне значення для дослідження музичної спадщини українського народу. В деяких з цих збірників розміщені півчі азбуки, в яких подається не тільки перелік невменних знаків, а і їхнє тлумачення на розподілення на групи за напрямком руху мелодії та ритмікою. Значна частина богослужбових півчих збірок залишається недостатньо дослідженою, що, своєю чергою, стримує рух у плані розшифрування невменного нотопису.

Аналіз останніх досліджень і публікацій. Дослідженням рукописних півчих збірок із колекції фондів Інституту рукопису Національної бібліотеки України імені В. І. Вернадського займалися О. А. Іванова та Л. А. Дубровіна. Науковці провели аналіз рукописних півчих збірок Міней, Тріодей i Октоїха. Результати своїх досліджень вчені виклали у своїх працях «Кирилична рукописна книга XVI ст. 3 фондів Інституту рукопису Національної бібліотеки України імені В. І. Вернадського» [2] та «Півчі богослужбові книги у репертуарі рукописних книг XVIcr. у фондах Інституту рукопису Національної бібліотеки України імені B. I. Вернадського» [3]. Головну увагу О. А .Іванова та Л. А .Дубровіна сконцентрували на загальному описі рукописів та їх змісту. Проводячи опис рукописних збірок були встановлені приблизні роки їхнього написання, що в певній мірі дає можливість прослідкувати хронологію створення півчих азбук.

Дослідженням рукописних півчих азбуктлумачень займався російський вчений М. В. Бражніков. У праці «Древнерусская теория музыки. По рукописным материалам XV-XVIII веков» вчений проводить аналіз азбук-тлумачень, написаних в XVI - XVII ст. М. В. Бражніков зазначає, що проаналізовані рукописні півчі азбуки не дають можливості в повній мірі розшифрувати стародавні тлумачення та перекласти невменні знаки на сучасну нотацію [1].

Серед українських вчених-теоретиків дослідженням рукописних півчих азбук займалися
Ю. П. Ясиновський та М. І. Качмар. Вони грунтовно дослідили півчу азбуку із Лаврівського невменного ірмологіону XVI століття [10].

Метою роботи $\epsilon$ проведення палеографічного опису та виявлення характерних особливостей у формуванні азбук-тлумачень в XVIII XIX ст.

Виклад проблеми. Починаючи XVII ст., в рукописних півчих збірниках набули поширення півчі азбуки, в яких подавався не тільки перелік невменних знаків («имєна столповому знамєни како котороє зовєтсА») а і їхне тлумачення («Сказаніє.. како поєтсА⿱»). Це «сказанія» (пояснення) мелодійного, висотного, ритмічного значення невменних знаків та співзвуччя між ними. Невмненні знаки певних груп в азбукахтлумаченнях описуються в звуковисотних відмінностях один до одного - у вигляді висхідних «Лествиць» крюків («Мрачный повышше, свьтлыи й паки повыше, тресвЬтлыи й того повы(ше), а (трисветлий) с сорочьєю ношкою велми высоко...»). 3 появою та поступовим закріпленням в півчих азбуках трисвітлих невменних знаків в стовповому (невменному) розспіві прослідковується тенденція до розширення верхнього діапазону звуковедення під час виконання богослужбових піснеспівів.

Аналізуючи рукописний збірник Азбука співоча ф. 301, № 638 п, маємо зазначити, що він написаний в 1823 р. Загальна кількість аркушів рукопису становить - 84. Формат рукопису Папір $4^{\circ} \quad(214 x 168)$. Рукопис написаний півуставом, одного почерку, чорнило чорне. Рукопис реставрований наприкінці XIX століття. Заголовні ініціали прикрашені рослинним жипописом жовтою, зеленою i коричневою фарбами. Кінцівка тексту закінчується колофоном 3 кольоровою композицією - в центрі гранатове яблуко від якого розходяться в різні боки дві гілки 3 різнокольоровим листям. Зміст рукопису: Азбука-перелік (арк. 1); «Сказаніс $\omega$ помbте вслкой прилучающейсА во всьмъ пьній столповомъ» (арк. 7); Ліствиця співоча (горовосходный холм) 3 написом «Началноє оучєніє члкомъ хотАщимъ оу читисія ста(р $\omega)$ сєго пьнїА»; «Лица и ро(3)воды фитамъ» (арк 48) [11]. 
Текст півчої азбуки починається вступним словом: «ЗдЬ написахо(м) имєна столповому знамєни како котороє зовєтсА. Мыже се $\omega$ прєдковъ своихъ которїи быша пьснотворцы й пьснорачитєлї, $\omega$ ни(х)жє мнози оугодиша бгу навыкохо(м) й прєи(м)ствовахом трєбующимъ прєдлагаємъ. Тыжє пьснорачителю Фсємъ внимай, Фнижнї^ стєпєни навышнюю возступай, радико а нєльносно прильжи, іазыкъ жє свій ФвсАкаго Мла оудєржи;» (Рис. 1).

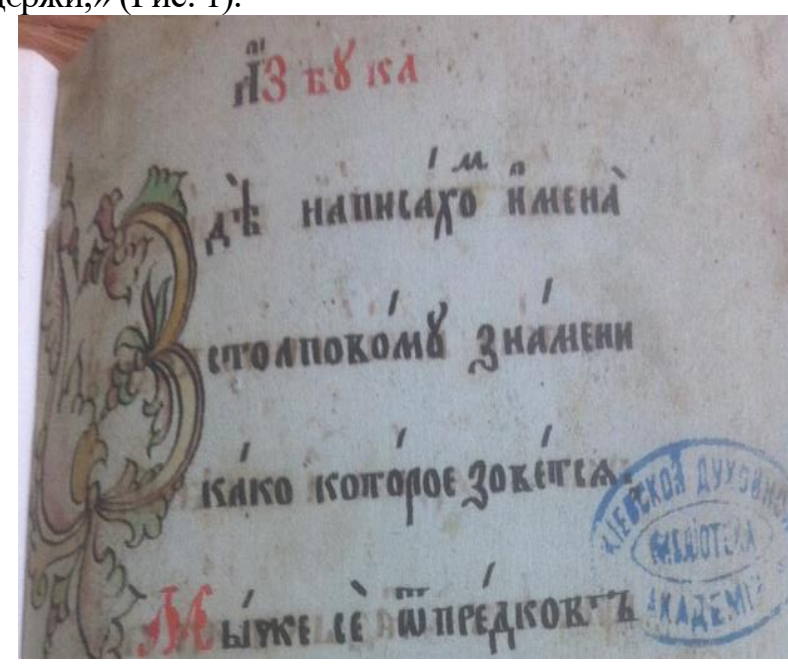

Рис. 1. Фрагмент із Азбуки-півчої

Більшість невменних знаків у першій частині півчої азбуки, а саме в переліку, повторюються і в другій іiі частині, де подається тлумачення цих невм. Для того, щоб уникнути повторень під час палеографічного аналізу та роз'яснення тлумачень перша і друга частини півчої азбуки розглянемо разом.

«Параклить ступити мьрностїю срєднєю, й во(3)гласити однажды такоже протику помьты красныл». За твердженням М. I. Качмар [4] тривалість цього знаку «відповідає половинній». Інша гіпотеза висловлена М. В. Бражніковим, що паракліт в давні часи був «благословенням» всієї півчої азбуки. Майже постійне використання цього знаку в півчих азбуках, на думку вченого, пов'язано 3 використанням паракліта на початку вірша, або строки під час півчої практики. Вчений наводить кілька прикладів із півчих азбук, де паракліт прирівнюється до крюка світлого, що дає йому підстави відносити ці два невменнні знаки до третього висотного рівня (согласія світлого) $[1,74]$.

«Крюкъ простой - поєтсл в срєднихъ согласїАхъ воєди(н) гла(с). Мрачный повышше, свьтлыи тресвьтлыи й того повы(ше), а (трисветлий) с сорочьєю ношкою гласомъ». Таким чином, пояснюється чотири різновиди із групи крюків і визначається тільки умовна їхня звуковисотність, яка залежить від попереднього крюка. Зазначається, що крюк простий проспівується в «срєднихъ согласїАхъ воєди(н) гла(с)», тому можемо лише зазначити, що згідно степенних помет це значення відповідає третій ступені мрачного согласія ноті «мі». В толкованії не зазначаються певні інтервали між крюками, можливо тільки припустити відмінність між «повышшє», «паки повыше», «й того повы(ше)», «вєлми высоко йзакинуть гласомъ». Відсутні дані про тривалість і характер виконання цих невменних знаків.

«А подкрюкомъ (простим) чашка $\mathbf{v}$ ступити внизь дважды». «Крюкъ (простий) сподверткою $L^{v} \ldots$ двь поступки внизъ». У другій частині півчої азбуки відсутнє пояснення як виконувати крюк трисветлий 3 оттяжкою. Також на початку азбуки в переліку подаються крюк світлий $з$ чашкою, крюк світлий $з$ подверткою, та крюк світлий $з$ сорочою ногою, а в другій частині подається тлумачення крюка простого $з$ чашкою, крюка простого 3 подверткою та крюка трисвітлого з сорочою ногою. Таке неспівпадіння можна пояснити тим, що автор азбуки вважав за потрібне пояснити більш складні невми, а зазначені в переліку крюки не потребують тлумачення.

«Стопица $L$ - воєдинъ гласъ». «Стопица со ючкомъ $L . . .$. двь поступки внизъ». «Стопица» вказує на речитатив і використовується на складах тексту, які не мають наголосу та в більшості випадків вказує на повторення одного тону (Металлов, 1899).

«Два вчєлну» لط качати гласомъ, прилучаєтсА й во(з)дергнутаА когда поєтсА книзу». Пояснення цього невменного знаку в півчих азбуках XVII ст. практично однакове. Прийнято вважати, що тривалість цього знаку чотири четвертних. В більш пізніх півчих азбуках зустрічаються складені знаки: «два в челну» 3 поміткою «качка» та «два в челну» 3 поміткою полкулизми большой<smiles>C1CCC1</smiles>
в перекладі на сучасну нотацію має такий вигляд

«Подчашїе (просте) $\ldots$ двь поступки внизъ». Ця група невменних знаків подібна до стріл і крюків та має чотири різновиди: «простоє», «мрачноє», «свЬтлоє», «прєсвЬтлоє». В тлумаченні не подається інформація про 
виконання подчаший мрачного $\stackrel{\sim}{*}$, світлого та трисвітлого

«Пєрєводка» " вдва гласа в вєрхь скоробъжно». Означає рух мелодії вгору двома четвертними. «Пєрєводка с помьтою тихою (кіноварна риска) $t^{\prime}-$ ступити в вєрхъ тихогласно». Це також рух мелодії вгору тільки двома половиними нотами.

«Скамєйца» $\rightarrow$ вдва гласа в вєрхь скоробьжно». «Скамейца» (проста) це рух мелодії двома четвертними вверх. «Тиха^» (скамейца)

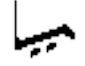
також рух мелодії вверх, але двома половинними.

«Голубчи(к) тихой $\boldsymbol{A}^{*}-$ ступити в вєрхъ тихогласно», тобто це дві половинні ноти які також поступово рухаються вгору. «Голубчикь борзой А... вдва гласа в вєрхъ скоробьжно» поступальний рух двох четвертних вгору. Голубчик як і переводка не має степенної помети, відповідно їхня висота залежить від наступного невменного знаку.

«Змєйца» - не має пояснення в тлумаченні.

«Дєрбица» АА - борзо вчєтырє поступки в вер(х)». Це чотири четвертні, які рухаються вгору.

«Хамило» A тихо прилучаєтс^, й вдва гласа смотрА на приступъ». Висота цього знаку залежить від гласу та висоти попереднього невменного знаку i за тривалістю, за одними даними рівняється четверті, за іншими - цілій ноті [7]. Наступний звук триває цілу ноту. Мелодія може рухатися або вгору, або вниз залежно від певного піснеспіву.

«Палка» $\rceil$ та (палка) «з зад(є)ржкою» \. «Палка - воєдинъ гласъ». В більшості випадків знак палки використовується наприкінці піснеспіву i означає зупинку в співі, або його закінчення та відповідає четвертній. Зустрічається палка 3 подверткою $\rceil v$ та палка з ломкою ${ }^{\wedge \circ}$ ๆ. В першому варіанті це рух мелодії вниз двома четвертними, в другому - рух мелодії вгору.

«Чашка простал $৩ .$. двь поступки внизъ». Подібне визначення зустічається в інших півчих азбуках, а саме чашка означає рух мелодії вниз двома четвертними. Чашка повна $\boldsymbol{\bullet}$ - також рух мелодії вниз, але спочатку половинна нота а потім

дві четвертні $\bullet$.

«Сложитїє» ฟ, «с запАтою» $/$ ^. «СложитїА в прилучїи палка \-двь поступки внизь». Це тлумачення підтверджується в більш пізніх півчих азбуках, де зазначається, що «СложитиА» означає рух мелодії вниз двома четвертними. Сложитіє iз зап'ятою це також рух мелодії вниз, але до двох четвертних додається половина нота • • 。 .

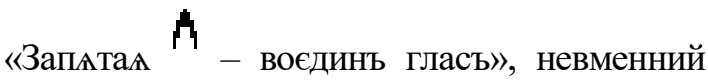
знак рівний половинній ноті. «Скрыже(м)» (зап'ята) А† означає окремий невменний знак, який рівний цілій ноті. Цей знак використовується для позначення низьких звуків на початку піснеспіву, або строки [6].

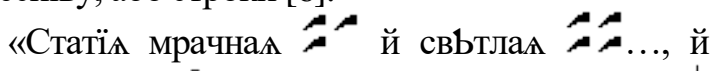

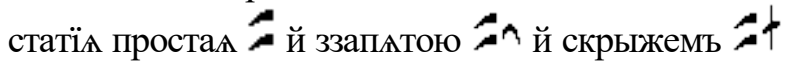
поютсА воєди(н) глась, высокость й низость іавьствуєть помьта». «Воздєргнутал (статї^) ) поютсА воєдинъ глась восвоихъ прилучїАхь зачатїю мьрностїю». Д. В. Разумовський (Разумовский, 1886) та С. В. Смоленський [9] стверджують, що «статї^» наприкінці строки більш тривала і після іiі звучання має бути пауза перед початком нової строки. Зазвичай, статії ставляться наприкінці піснеспіву.

«Фотиза» (статія закрита середня 3 сорочою ногою) Звуковисотність між різновидами статій, в даній півчій азбуці, не визначаєься, є тільки посилання на помети, які визначають «высокость й низость» виконання. Останні п'ять різновидів статій не мають пояснення, щодо виконання:

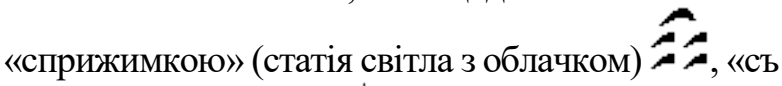
сорочьєю ношкою» $\boldsymbol{\sim}$, «закрытах малаА» $\boldsymbol{\sim}$ «закрыта^ бо(л)ша(^)» (статія закрита середня) ㄱ.

«Стрьла мрачнал тихогласно». «Стрьла простаА воєди(н) глась, высокость й низость іавьствуєть помьта». «Стрьла громосвьтлаА 3 замьткою (сорочою ногою) Аһ поступки в вер(х)». Це дає підстави стверджувати, що стріла громосвітла 3 сорочою ногою має п'ять звуків, які рухаються в гору. «Стрьлы же свьтлаА

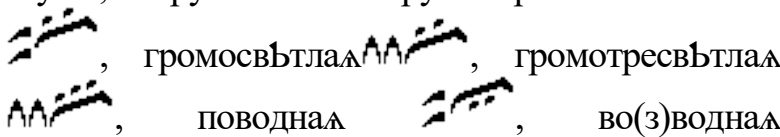

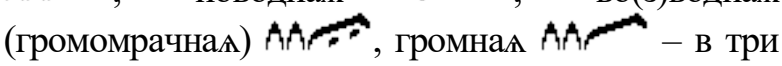
поступки поютсл догоры» (Рис. 2). Відповідно всі зазначені різновиди стріл мають по чотири звуки, які також рухаються вгору. 


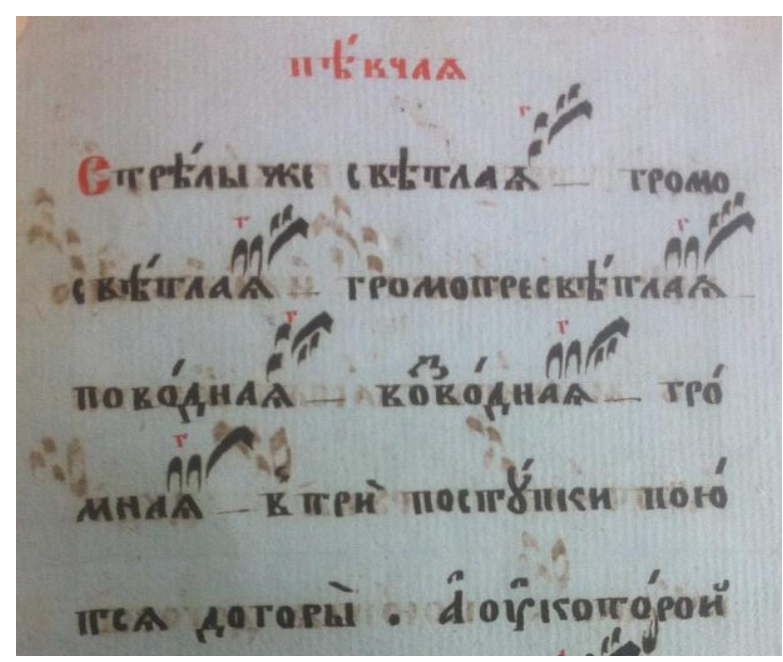

Рис. 2. Фрагмент із Азбуки-півчої

«А оукоторой прилучитсА соколєцъ (стріла світла 3 сорочою ногою) голоса непо(с)тол(н)но. Аще сподвєрткою Аще сподверткою тогда в четыре тогда сносить голось нанизъ іякоже й поєзднаА

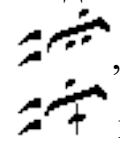
а крыжева^ (стрела мрачнал с крижом) в двь поступки въвєрхъ». «А гдЬ прижимка (стрела крижева^ с протягненим облачком)

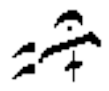
йли ббла(ч)ко (стрела проста^ с протягненим облачком) 2 ту мрачнить гласомъ - поютсл догоры вчєтырє гласа». Залишається не 3'ясованими тривалість звуків та інтервальне співвідношення між ними. Чотири стріли не мають будь-яких поясненнь як виконувати - «3 задєржкою» (стріла світла із затримкою) «со юблачко(м)» (стріла світла з облачком) , «счашкою» (стріла світла 3 чашкою) «полукрыжєваА» (стріла громосвітла 3 крижом) Art

У переліку зазначені такі різновиди кулизм: «По(л)кулизмы» $\boldsymbol{\sim}$ (статія проста 3 подверткою), «кулизма средни(А)» $\boldsymbol{\sim} \boldsymbol{\sim} \boldsymbol{\sim}$, «кулизма болшам》 急, (полкулизми середня, статія закрита, статія проста) «полкулизмы болшім» (полкулизми середня), «воздергнутал» )․ В другому розіділ подаються пояснення до цих невменних знаків: «Полкулизмы حُ («статї^ проста 3 подвєрткою) качати гласомъ, прилучаєтсл й во(з)дергнутал книзу». «Күлизмы болшаА, й срєднА^ во всьхъ гласьхъ поютсл вслкими разными попьвками непо(с)тол(н)но». Висота та послідовність звуків кулизми залежить від гласу і місця розташування в піснеспіві, а також від попередніх невменних знаків.

«Челюстка» $\grave{2}$ - поєтсл воєдинь глась восвоихъ прилучїлхъ зачатїю мьрностїю». Цей невменний знак означає цілу ноту і в більшості випадків використовується наприкінці мелодичного звороту (Качмар, 2018).

«Ключь» - поєтсл воєдинь глась восвоихъ прилучї^хъ зачатїю мьрностїю». Цей знак за тривалістью рівняється цілій ноті. В більшості випадків «ключь» використовується разом 3 «Переводкою» або «Челюсткою» i виконується в гласах по різному.

«Трлска» (трясогласна) 2 во всьхь гласьхъ поєтсА вслкими разными попьвками непо(с)тол(н)но». Цей невменний знак стоїть окремо від групи стріл, так як має своєрідне виконання. Спочатку мелодія плавно рухається вниз, потім піднімається в гору на один тон і знову

вниз
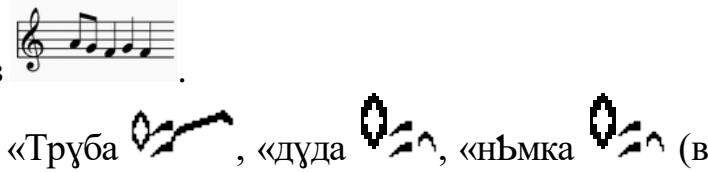
інших джерелах цей знак має таке зображення H- ) - поютсл догоры вчєтыре гласа». Це не зовсім точне визначення, так як ці невменні знаки мають певні відмінності. Труба - рух мелодії вгору четвертними і половиними, де останій звук має тривалість рівну цілій ноті. Немка - рух мелодії вгору, де останній четвертий звук плавно рухається вниз зображення дуди і немки дає підстави вважати і про подібність виконання. Це тільки гіпотеза, яка потребує подальшого дослідження.

«Паоу(к) малой» $\boldsymbol{\gamma}^{\wedge}$, «болшой» $\boldsymbol{\sim} \boldsymbol{\sim} \boldsymbol{\gamma}^{\wedge}$ (статія закрита, статія проста і паук). «Паоуки во всьхъ гласьхъ поютсл вслкими разными попьвками непо(с)тол(н)но». Тривалість, висота i направлення звуків «паука» в гласах визначається по різному.

«Мєчикь во всьхь гласьхь поєтсл вслкими разными попьвками непо(с)тол(н)но». Цей невменний знак в більшості випадків використовується наприкінці піснеспівів i в сучасній нотації має такий вигляд

«Рогъ $\mathcal{Z}$ ставитсл прифитахъ оукрашенї ради, агдь наконцьхъ тогда кнєму кончаєтсА пьтыи стихъ застатїю воєди(н) гла(с) іакоже й крыжекъ». «Рогъ» ставився наприкінці піснеспіву і за тривалістю був рівний цілій ноті.

«Фита» $\hat{\mathbf{v}}$ - не має пояснення в тлумаченні. На початку третьої частині півчої азбуки зазначається: «Сказанїє $\omega$ помьтє вслкой 


\section{Вісник Національної академії керівних кадрів культури і мистецтв № 2'2о20}

прилучающейсл во всьмъ пьнїи столповомъ. Подобаєть вьдати, аще стоить оу ту оударить, а гдь б тамо пой борзо, й дьжє 3 то закинь борзо, а гдь т түть пой тихо, ащє к навєрху знамєни то качай, а нижє знамєни тамъ такжє, й дьжє ло түть ломи. А гдь р пой равно колико и(х) прилучытсл быти»; Сказанїє пачєжє показанїє, котороє знамА скоторымъ мьрностїю єдинство ймьєть, аще й разновидно разумьнїємъ йгласоступанїє(м) єдинако» (Рис. 3).

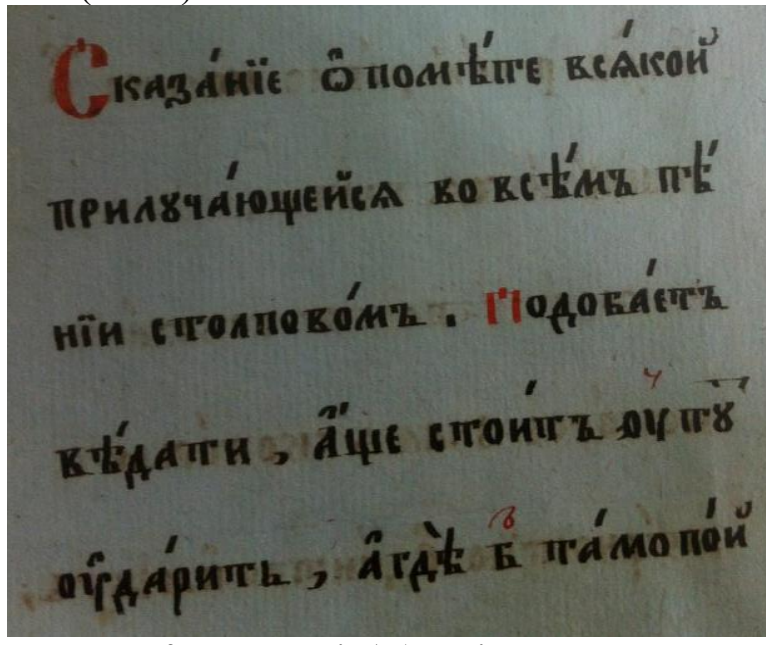

Рис. 3. Фрагмент із Азбуки-півчої

У третій частині азбуки подаються групи невменних знаків, які сформовані за напрямком руху мелодії та ритмікою:

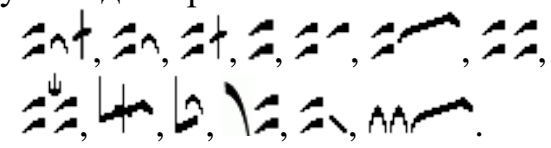

«Сїє выше писанное знамА пой воєди(н) гла(с) тА(го)тою вєликою». Це такі невменні знаки: статія 3 зап'ятою та крижем, статія 3 зап'ятою, статія проста 3 крижем, статія проста, статія мрачна, стріла проста, статія світла, статія світла з сорочою ногою, ключ, челюстка, статія воздернута, статія закрита, стріла громна. Більшість із вказаних невменних знаків становить група статій. Зазначені невми мають доволі довгу тривалість, яка рівна половинним та цілим нотам.

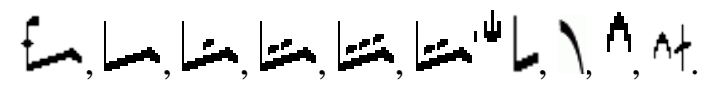

«Сіи знамєны ступай воєди(н) гласъ мърою вполы против Фного». Це - паракліт, крюк простий, крюк мрачний, крюк світлий, крюк трисвітлий, крюк світлий 3 сорочою ногою, стопиця, палка, зап'ята, зап'ята з крижом. В другій групі більшість знаків становлять різновиди крюків, починаючи від крюка простого до крюка трисвітлого 3 сорочою ногою. Висота кожного наступного неменного знаку є вище попереднього.

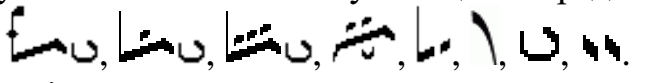

«Сіи знамєны поютсл долу въдвь поступки борзо». Це - паракліт з подчашиєм, крюк мрачний
3 подчашиєм, крюк трисветлий 3 подчашиєм, подчашиє світле, стопица 3 очком, палка, чашка проста, сложитіє. Значна частина невменних знаків має подчашиє. Рух мелодії, при виконанні цих знаків, йде вниз невеликими за тривалістю звуками (четвертними). Дві поступки борзо відповідають трьом четвертним.

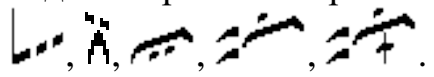

«Сіи знамєны пой догоры въ двь поступки борзо». Це - стопиця 3 двома очками, голубчик борзий, скамеїца, стріла мрачна, стріла мрачна 3 крижом. На противагу попередній групі невм мелодія з цими невменним знаками виконуються вгору трьома четвертними.

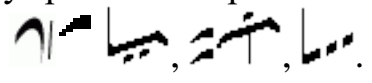

«Сіи знамєны ступаютсл тихо догоры въдвь поступки». Це - голубчик тихий, скамейца тиха, стріла мрачна 3 тихою пометою, стопиця 3 двома очками. В перших трьох невменних знаках присутня помета «тиха», а виконання останньої невми стопиці 3 двома очками залежить від оточуючих його знаків. При виконанні піснеспіву 3 цими невменними знаками мелодія рухається також вгору тільки більш тривалими звуками половинними та цілими нотами.

«Вси онїи вышєписаннїи разнозритєлнїи знамєны в кіи любо гласъ пьти высоко(с)ть й низость гласомъ такожде й тихость й борзость, іавьствовать будуть приних случайшыл помьты красныА». Ці останні слова з азбуки є поясненнням Ліствиці співочої з написом «Началноє оучєніє члкомъ ХотАщимъ оу читисія ста $($ р $\omega)$ сєго пьнї^», в якій подаються невменні знаки 3 кіноварними степенними пометами.

Висновки. Палеографічний аналіз Азбуки співочої ф. 301, № 638 п дав можливість виявити певні закономірності, знайти спільні риси та відмінності 3 іншими півчими азбуками. Розглянувши рукописні збірки, потрібно зазначити, що, починаючи із XVII ст., півчі азбуки мають не тільки перелік невм, а й їхнє тлумачення та розділення невменних знаків на групи за виконанням. Наповнення невменними знаками азбук, як і в XVI ст., так і в наступних століттях, відбувалося відповідно до їхнього використання під час півчої практики. Як правило, в азбуку вносилися ті знаки, які вважалися найбільш важливими у виконанні церковних піснеспівів. Також прослідковуються певні відмінності між переліком та тлумаченням невменних знаків у півчих азбуках. Під час проведення дослідження було підтверджено характерні ознаки які існували в XVI - XVII ст. і збереглися в XIX ст., а саме при формуванні півчих азбук на першому місці ставилася назва невменного знаку, а потім його різновид без повторення назви знаку. 
Проаналізовано п'ять груп невматичних знаків, які розташовані наприкінці півчої азбуки. Визначено їхні характерні особливості: встановлено їхню звуковисотність, кількість звуків та мелодичну направленність. Виявлені істотні розбіжності в трактуванні способу виконання певних невматичних знаків серед вчених-медієвістів. Проведений аналіз ще раз продемонстрував необхідність дослідження інших півчих рукописів 3 метою зібрання максимально повної інформації про півчі азбуки та розробки єдиного трактування виконання невменних знаків та кіноварних степенних і вказівних помет.

\section{Jimepamypa}

1. Бражников М.В. Древнерусская теория музыки. По рукописным материалам XV-XVIII веков. Москва: Музыка, 1972. 422 с.

2. Іванова О.А. Кирилична рукописна книга XVI століття 3 фондів Інституту рукопису Національної бібліотеки України імені В.I. Вернадського. Історикокодикологічне дослідження. Альбом філіграней. Київ: НБУВ, 2016. $256 \mathrm{c}$.

3. Іванова О.А., Дубровіна Л.А. Півчі богослужбові книги у репертуарі рукописних книг XVI століття у фондах Інституту рукопису Національної бібліотеки України імені В. І. Вернадського. Рукописна та книжкова спадщина України. Київ, 2003. Вип. 8. C. 71-79.

4. Качмар М.I. Азбука кулизмяного ірмологіону XVI ст. Українська музика, 2018 Вип. 1 (27). С. 115-119. URL: $\quad$ file:///C:/Users/User/Downloads/Ukrmuzyka_ 2018_1_17.pdf.

5. Крюковой букварь. URL: http://dyakoko.mrezha.ru/bukvar/lesson1.html.

6. Металлов В.М. Азбука крюкового пения. Опыт систематического руководства к чтению крюковой семиографии песнопений знаменного роспева, периода киноварных помет. Москва: Синод. типография, 1899. $130 \mathrm{c}$.

7. Николаев, Б.Н. Знаменный распев и крюковая нотация как основа русского православного церковного пения. Москва: Талан, 1995. 300 с.

8. Разумовский, Д.В. Теория и практика церковного пения. Москва: типография О.О. Гербека, 1886. $172 \mathrm{c}$.

9. Смоленский, С.В. Азбука знаменнаго пенія (извещеніе о согдаснейшихъ пометахъ) старца Александра Мезенца. Казань: типография Императорского Университета и типо-литография Н. Данилова, 1888. $132 \mathrm{c}$.

10. Ясіновський Ю.П. Українські та білоруські кулизмяні пам'ятки XVI століття. К $\alpha \lambda \circ \varphi \omega v i ́ \alpha, 5$. Львів, 2010. C. 341-342. $1823 \mathrm{p}$.

11. НБУВ, ф. 301 , № 638 п. Азбука співоча. Київ,

\section{References}

1. Brazhnikov M.V. (1972). Old Russian theory of music. Based on handwritten materials of the XV-XVIII centuries. Moscow: Music. 422 p. [in Russian].
2. Ivanova O. A. (2016). Cyrillic manuscript book of the XVI century. from the holdings of the Institute of Manuscripts of the VI National Library of Ukraine Vernadsky: Historical and codicological study. Filigree Album. Rep. ed. L.A. Oakwood. Kyiv: NBUV. 256 p. [in Ukraine].

3. Ivanova O. A., Dubrovina L. A. (2003). Semi liturgical books in the repertoire of manuscripts of the XVI century. in the holdings of the Institute of Manuscripts of the VI Vernadsky National Library of Ukraine. Manuscript and book heritage of Ukraine. Issue 8. C. 71-79. [in Ukraine].

4. Kachmar M.I. (2018). The alphabet of the kulmismal irmologist of the 16th c. Ukrainian Music. Issue 1 (27), pp. 115-119 URL: file: /// C: /Users/User/ Downloads/Ukrmuzyka_2018_1_17.pdf. [in Ukrainian].

5. Hook primer. (2015). URL: http://dyakoko.mrezha.ru/bukvar/lesson1.html. (in Russian).

6. Metallov V.M. (1899). The alphabet of hook singing. The experience of a systematic guide to reading the hook semiography of chants of the znamenny chant, the period of cinnabar litters]. Moscow: Synod. printing house. 130 p. [in Russian].

7. Nikolaev B.N. (1995). The famous chant and hook notation as the basis of Russian Orthodox church singing. Moscow: Talan. 300 p. [in Russian].

8. Razumovsky D.V. (1869). Church singing in Russia. Moscow. 1st issue 1867; 2nd issue 1868; 3rd issue All in all three issues. 362 p. [in Russia].

9. Smolensky S.V. (1888). Alphabet of the famous penny (notice of the most recent litters) of the elder Alexander Mezenets. Kazan: typography of the Imperial University and typographic lithography of N. Danilov. 132 p. [in Russian].

10. YasInovskiy Yu.P. (2010) Ukrainian and Belarusian kulizmiani monuments of the XVI century.

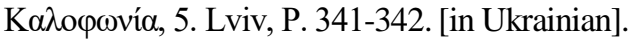

11. NBUV, f. 301 , No. 638 p. (1823) The alphabet is singing. Kyiv. [in Ukraine].

Стаття надійшла до редакиії 13.01.2020 Прийнято до друку 14.02.2020 